\title{
Differential responses to salt supplementation in adult male and female rat adrenal glands following intrauterine growth restriction
}

\author{
Karine Bibeau ${ }^{1,2}$, Mélissa Otis ${ }^{3}$, Jean St-Louis ${ }^{1,2}$, Nicole Gallo-Payet ${ }^{3}$ and Michèle Brochu ${ }^{1,2}$ \\ ${ }^{1}$ Research Centre, CHU Sainte-Justine, 3175 Côte Ste-Catherine, Montréal, Québec, Canada H3T 1C5 \\ ${ }^{2}$ Department of Obstetrics and Gynecology, Université de Montréal, Montréal, Québec, Canada H3C 3T7 \\ ${ }^{3}$ Service of Endocrinology, Faculty of Medicine and Health Sciences, Université de Sherbrooke, Sherbrooke, Québec, Canada J1H 5N4 \\ (Correspondence should be addressed to M Brochu at Research Centre, CHU Sainte-Justine; Email: michele.brochu@umontreal.ca)
}

\begin{abstract}
In low sodium-induced intrauterine growth restricted (IUGR) rat, foetal adrenal steroidogenesis as well as the adult reninangiotensin-aldosterone system (RAAS) is altered. The aim of the present study was to determine the expression of cytochrome P450 aldosterone synthase (P450aldo) and of angiotensin II receptor subtypes $1\left(\mathrm{AT}_{1} \mathrm{R}\right)$ and $2\left(\mathrm{AT}_{2} \mathrm{R}\right)$ in adult adrenal glands and whether this expression could be influenced by IUGR and by high-salt intake in a sex-specific manner. After 6 weeks of $0.9 \% \mathrm{NaCl}$ supplementation, plasma renin activity, $\mathrm{P} 450$ aldo expression and serum aldosterone levels were decreased in all groups. In males, IUGR induced an increase in $\mathrm{AT}_{1} \mathrm{R}, \mathrm{AT}_{2} \mathrm{R}$, and $\mathrm{P} 450$ aldo levels, without changes in morphological appearance of the zona glomerulosa $(\mathrm{ZG})$. By contrast, in females, IUGR had no effect on the expression of
\end{abstract}

$\mathrm{AT}_{1} \mathrm{R}$, but increased $\mathrm{AT}_{2} \mathrm{R}$ mRNA while decreasing protein expression of $A T_{2} R$ and $P 450$ aldo. In males, salt intake in IUGR rats reduced both $A T_{1} R$ mRNA and protein, while for $A T_{2} R$, mRNA levels decreased whereas protein expression increased. In females, salt intake reduced ZG size in IUGR but had no affect on $\mathrm{AT}_{1} \mathrm{R}$ or $\mathrm{AT}_{2} \mathrm{R}$ expression in either group. These results indicate that, in response to IUGR and subsequently to salt intake, $\mathrm{P} 450 \mathrm{aldo}, \mathrm{AT}_{1} \mathrm{R}$, and $\mathrm{AT}_{2} \mathrm{R}$ levels are differentially expressed in males and females. However, despite these adrenal changes, adult IUGR rats display adequate physiological and adrenal responses to high-salt intake, via RAAS inhibition, thus suggesting that extra-adrenal factors likely compensate for ZG alterations induced by IUGR.

Journal of Endocrinology (2011) 209, 85-94

\section{Introduction}

The renin-angiotensin system (RAS) via angiotensin II (Ang II) plays a key role in the regulation of blood pressure and hydro-mineral balance through the control of vascular tone and in renal sodium reabsorption either directly or through stimulation of adrenal aldosterone production (Schiffrin \& Touyz 2004, Hunyady \& Catt 2006, Otis \& Gallo-Payet 2007, Otis et al. 2007). Ang II binds two major receptors, the Ang II type-1 receptor $\left(\mathrm{AT}_{1} \mathrm{R}\right)$ and type-2 receptor $\left(\mathrm{AT}_{2} \mathrm{R}\right)$. Binding of Ang II to the widely expressed $\mathrm{AT}_{1} \mathrm{R}$ plays a predominant role in the capacity of the adrenal zona glomerulosa (ZG) to produce aldosterone (Capponi 2004, Schiffrin \& Touyz 2004, Hunyady \& Catt 2006) via cytochrome P450 aldosterone synthase (P450aldo; Bassett et al. 2004, Capponi 2004). In contrast to several adult tissues, $\mathrm{AT}_{2} \mathrm{R}$ is relatively highly expressed in the adult adrenal glands (ZG and medulla; Breault et al. 1996, Frei et al. 2001, Macova et al. 2008). In various pathological situations, it is generally assumed that Ang II stimulation of the $\mathrm{AT}_{2} \mathrm{R}$ counteracts the effects of $\mathrm{AT}_{1} \mathrm{R}$ (de Gasparo et al. 2000, Schiffrin \& Touyz 2004).

Interestingly, the RAS has been identified both as a target for the programming of adult diseases (McMillen \& Robinson

2005) and as an important contributor for the detrimental cardiovascular consequences of salt intake (Meneton et al. 2005). In our laboratory, an animal model of impaired foetal growth was developed by administering a low-sodium diet to rats during the last week of gestation (Roy-Clavel et al. 1999), inducing an important activation of the maternal reninangiotensin-aldosterone system (RAAS) in comparison to normal pregnant rats (Bedard et al. 2005). We recently showed that $\mathrm{AT}_{1} \mathrm{R}$ and $\mathrm{P} 450$ aldo mRNA expression was enhanced in intrauterine growth restriction (IUGR) foetal adrenal glands and was associated with an increase in serum aldosterone levels (Bibeau et al. 2010). Since Ang II does not cross the placenta (Clark et al. 1990), these changes are not dependent on maternal RAAS over-activation observed in low-sodium restricted dams. As young adults (12-week-old), offspring of this IUGR model have been shown to manifest a modest increase in systolic blood pressure, but a disrupted RAAS as well as renal dysfunction, evidenced by reduced glomerular filtration which was not related to a lower number of glomeruli (Battista et al. 2002). These modifications were less pronounced in IUGR males, suggesting differing effects between adult males and females following these adverse intrauterine conditions. Such observations have also been 
reported in IUGR induced by a low-salt diet prior to and throughout pregnancy (Lopes et al. 2008).

Since we previously showed that IUGR offspring of dams on a low-sodium diet exhibit altered foetal adrenal steroidogenesis (Battista et al. 2002, 2005, Bibeau et al. 2010), we hypothesized that the regulation of aldosterone secretion by adrenal glands is likely influenced by IUGR. The aims of the present study were therefore to characterize the consequence of IUGR on adult male and female adrenal glands (histology, $\mathrm{AT}_{1} \mathrm{R}$ and $\mathrm{AT}_{2} \mathrm{R}$ expression, and steroidogenesis) and, secondly, to determine whether adrenal glands of these IUGR offsprings are vulnerable to the influence of $0.9 \% \mathrm{NaCl}$ supplementation.

\section{Materials and Methods}

\section{Animals, experimental design, tissue preparation and physiological measurements}

This study was approved by our institutional Animal Care Committee, which is accredited by the Canadian Council on Animal Care. Female Sprague-Dawley rats (Charles River Canada, St-Constant, Québec, Canada) weighing 225-250 g were mated with a known fertile male. Day 1 of pregnancy was determined by the presence of spermatozoa in morning vaginal smears. All animals were housed under controlled lighting $(0600-1800 \mathrm{~h})$ and temperature $\left(21 \pm 3{ }^{\circ} \mathrm{C}\right)$. The dams were randomly assigned to one of two diets for the last 7 days of gestation (term $=$ day 23). One group $(n=13$ dams) were fed a normal diet containing $0 \cdot 2 \%$ sodium (basal diet 5755; PMI Feed, Inc., Ren's Feed and Supplies, Oakville, Ontario, Canada) and tap water. They gave birth to the control offspring group. The second group ( $n=14$ dams) received a $0 \cdot 03 \%$ sodium diet (low-sodium diet 5881; PMI Feed, Inc.) and demineralized water. Their offspring suffered from IUGR (Battista et al. 2002). After parturition, all dams received a regular diet $(0 \cdot 23 \%$ sodium, Tecklab global $18 \%$ protein rodent diet 2018, Harlan Tecklab, Montréal, Québec, Canada) and tap water. Litters were not culled because in a previous report (Roy-Clavel et al. 1999) we showed that litter size was unaffected by the maternal low-sodium diet (IUGR: $13 \pm 1$ pups versus control: $14 \pm 1$ pups). The control and IUGR animals were weaned at 4 weeks of age and separated into male and female sub-groups. At 6 weeks of age, males and females were randomly separated into two additional groups $(0 \cdot 9 \%$ $\mathrm{NaCl}$ supplementation and non-supplemented), according to whether or not they received the sodium supplement $(0.9 \% \mathrm{NaCl}$ in tap water), until killed at 12 weeks.

At the end of week 12, body weights were recorded for male and female (random undetermined oestrous cycle stage) animals which were then decapitated (0800-1000 h). Trunk blood was collected for hormone and electrolyte analysis. Adrenal glands were removed, weighed, and processed. Under manual compression, the adrenal cortex containing only the ZG was gently separated from the medulla to which the zona fasciculata/reticularis (ZFR) remained attached. For each litter, adrenal zonae glomerulosa or fasciculata/reticularis from two rats of the same sex were pooled (corresponding to $n=1)$. They were immediately snap-frozen in liquid nitrogen and stored at $-80^{\circ} \mathrm{C}$. For histological analyses, five adrenal glands per group were immediately immersed in $4 \%$ paraformaldehyde and subsequently embedded in paraffin. Sections ( $5 \mu \mathrm{m}$ thick) were cut and stained with haematoxylin and eosin for histological examination.

\section{Adrenal histology}

Before inclusion in paraffin, each ovoid gland was trimmed down to about one-third of its larger portion. Then, in the following serial $5 \mu \mathrm{m}$ sections, the section containing the largest diameter of medulla was chosen to measure the width of ZG. Slides were examined with a Nikon Eclipse 2000 inverted microscope (Nikon, Mississauga, Ontario, Canada) equipped for epi-illumination. Images were acquired with a Hamamatsu ORCA-ER digital camera using $10 \times$ or $20 \times$ objectives. The width of the ZG was measured on two slides representing the largest diameter of the gland, using the calliper integrated to the MetaMorph Imaging System v4.5 software package (Universal Imaging Corp., Westchester, PA, USA). Mean width was calculated using a parameter analysis module, with three separate measurements performed for each slide of the gland, and five glands in each group.

\section{Blood sample collection, hormone measurements and analysis}

After decapitation, a first blood sample $(0.5 \mathrm{ml})$ was collected into a vacutainer tube (Becton Dickinson, Franklin Lakes, NJ, USA) containing $15 \%$ dipotassium EDTA solution to quantify plasma renin activity (PRA). A second sample was drawn into a plain vacutainer tube to determine serum steroid concentration. A final blood sample was collected in a lithium heparin vacutainer tube for measurement of plasma electrolytes. After centrifugation of all blood samples at $1550 \mathrm{~g}$ for 20 min at $4{ }^{\circ} \mathrm{C}$, the serum or plasma was stored at $-80^{\circ} \mathrm{C}$.

PRA was quantified indirectly as described elsewhere (Roy-Clavel et al. 1999). Briefly, Ang I, generated per $2 \mathrm{~h}$ incubation period, was measured by RIA with an antibody purchased from Peninsula Laboratories (San Carlos, CA, USA; Gutkowska et al. 1977). Aldosterone and corticosterone were analyzed directly from serum with commercial RIA kits (aldosterone: Intermedico, Montréal, Québec, Canada; corticosterone: Medicorp, Montréal, Québec, Canada). Plasma sodium and potassium were measured with specific electrodes.

\section{$R N A$ isolation and reverse transcriptase-PCR}

Total RNA from six adrenal zonae glomerulosa or fasciculata/reticularis in each group was extracted by TRIzol Reagent (Invitrogen Canada, Inc.). Final RNA pellets were dissolved in an appropriate volume of diethylpyrocarbonated water and stored at $-80{ }^{\circ} \mathrm{C}$. RNA concentration was 
established by absorbance measurement at $260 \mathrm{~nm}$, with sample integrity ascertained by the $260 / 280 \mathrm{~nm}$ ratio. Quality was verified by ethidium bromide fluorescence.

PCR primers specific for the genes of interest were designed with PRIMER3 (www.genome.wi.mit.edu/cgi-bin/primer/ primer3_www.cgi), based on sequence data from the National Center for Biotechnology Information (Table 1). For $\mathrm{AT}_{1} \mathrm{R}$, since $\mathrm{AT}_{1 \mathrm{~b}}$ expression is the predominant form in the rodent adrenal gland (Gasc et al. 1994), the $\mathrm{AT}_{1 \mathrm{~b}}$ sequence primers were selected for our studies.

Single-stranded cDNA was created by reverse transcriptase (RT; SuperScript II RNase H-Reverse Transcriptase, Invitrogen) and PCR (Taq DNA Polymerase, Invitrogen) was performed according to the procedure detailed by the manufacturer. The annealing step was carried out for $1 \mathrm{~min}$ at temperatures established for each gene in adrenal ZG or ZFR (Table 1). The extension step was undertaken at $72{ }^{\circ} \mathrm{C}$ for $1 \mathrm{~min}$. PCR results were collected during the exponential phase, since the number of cycles needed for amplification was determined for each gene in each tissue (Table 1). To ensure that genomic DNA was not amplified, RT was performed without enzyme and PCR was conducted as previously described. PCR products were assessed by electrophoresis on $1 \%$ agarose gels and visualized by ethidium bromide fluorescence. Amplification products were quantified by Alpha Imager software (Alpha Innotech Corporation, San Leandro, CA, USA). The procedure was conducted on triplicate samples and the results reported on glyceraldehyde-3-phosphate dehydrogenase as internal control.

\section{$A T_{1} R$ and $A T_{2} R$ and $P 450 a l d o, P 45011 \beta$ protein expression}

Frozen adrenal zonae glomerulosa or zonae fasciculata/reticularis ( $n=6 /$ group) were homogenized in lysis buffer containing $50 \mathrm{mM}$ Tris- $\mathrm{HCl}$ buffer $(\mathrm{pH} 7 \cdot 4), 150 \mathrm{mM}$ $\mathrm{NaCl}, 1 \mathrm{mM}$ EDTA, $1 \% \mathrm{NP}-40,0 \cdot 25 \%$ sodium deoxycholate, and $1 \times$ complete EDTA-free protease inhibitor cocktail tablet (Roche) and centrifuged at $12000 \mathrm{~g}$ for $30 \mathrm{~min}$ at $4{ }^{\circ} \mathrm{C}$. Supernatants were collected and subsequently resuspended in Laemmli buffer. For comparative purposes, proteins $(25 \mu \mathrm{g}$ for $\mathrm{AT}_{1} \mathrm{R}, 10 \mu \mathrm{g}$ for $\mathrm{AT}_{2} \mathrm{R}, 50 \mu \mathrm{g}$ for P450aldo, and $20 \mu \mathrm{g}$ for $\mathrm{P} 45011 \beta)$ were separated by SDS-PAGE $\left(12 \%\right.$ for $\mathrm{AT}_{1} \mathrm{R}$ and $\mathrm{AT}_{2} \mathrm{R}$ and $10 \%$ for P450aldo and $\mathrm{P} 45011 \beta$ ) and then transferred electrophoretically onto nitrocellulose membranes (Fisher Scientific, Nepean, Ontario, Canada). Nonspecific sites on the membranes were blocked for $1 \mathrm{~h}$ at room temperature in $5 \%$ skim milk PBS $(1.4 \mathrm{M} \mathrm{NaCl}, 2.7 \mathrm{mM}$ $\left.\mathrm{KCl}, 100 \mathrm{mM} \mathrm{Na}_{2} \mathrm{HPO}_{4}, 17 \cdot 6 \mathrm{mM} \mathrm{KH}_{2} \mathrm{PO}_{4}, \mathrm{pH} 7 \cdot 4\right) / 0 \cdot 1 \%$ Tween-20. Overnight incubation at $4{ }^{\circ} \mathrm{C}$ was conducted with rabbit anti- $\mathrm{AT}_{1} \mathrm{R}$ (1/100; Santa Cruz Biotechnology, Inc., Santa Cruz, CA, USA), or $\mathrm{AT}_{2} \mathrm{R}$ (1/500; Santa Cruz Biotechnology, Inc.), mouse anti-P450aldo (1/500; Chemicon, Temecula, CA, USA), or P45011 $\beta$ (1/1000, Chemicon). Membranes were then washed and incubated with HRPconjugated anti-mouse or anti-rabbit IgG (1/5000; Amersham) for $45 \mathrm{~min}$ at room temperature. Equal protein
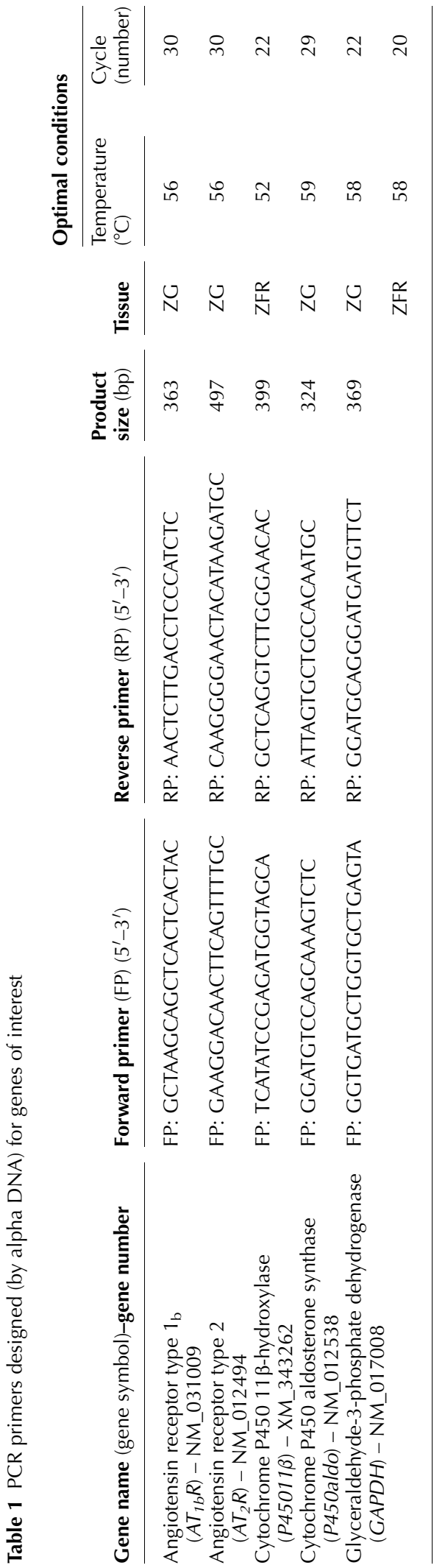

Journal of Endocrinology (2011) 209, 85-94 
Table 2 Effects of $0.9 \% \mathrm{NaCl}$ supplementation on body weight, adrenal gland weight and relative adrenal gland weight of 12 -week-old control and intrauterine growth restriction (IUGR) male and female rats. Results are expressed as means \pm s.E.M. $(n=20-25$ rats/group)

\begin{tabular}{|c|c|c|c|c|}
\hline & \multicolumn{2}{|l|}{ Control } & \multicolumn{2}{|l|}{ IUGR } \\
\hline & Non-supplemented & $0.9 \% \mathrm{NaCl}$ & Non-supplemented & $0 \cdot 9 \% \mathrm{NaCl}$ \\
\hline \multicolumn{5}{|l|}{ Males } \\
\hline Body weight (g) & $444 \pm 8$ & $445 \pm 8$ & $426 \pm 7$ & $430 \pm 5$ \\
\hline Adrenal gland weight (mg) & $57 \pm 2$ & $56 \pm 1$ & $56 \pm 2$ & $54 \pm 1$ \\
\hline Relative adrenal gland weight $\left(\% \times 10^{-3}\right)$ & $12 \cdot 8 \pm 0 \cdot 3$ & $12 \cdot 9 \pm 0 \cdot 3$ & $12 \cdot 9 \pm 0 \cdot 3$ & $12 \cdot 6 \pm 0 \cdot 3$ \\
\hline \multicolumn{5}{|l|}{ Females } \\
\hline Body weight (g) & $259 \pm 5$ & $266 \pm 6$ & $245 \pm 5$ & $261 \pm 5$ \\
\hline Adrenal gland weight $(\mathrm{mg})$ & $63 \pm 2$ & $67 \pm 2$ & $60 \pm 1$ & $62 \pm 2$ \\
\hline Relative adrenal gland weight $\left(\% \times 10^{-3}\right)$ & $24 \cdot 3 \pm 0 \cdot 8$ & $25 \cdot 3 \pm 0 \cdot 5$ & $24 \cdot 8 \pm 0 \cdot 3$ & $23 \cdot 5 \pm 0 \cdot 5$ \\
\hline
\end{tabular}

loading was determined on the same membrane with mouse anti- $\beta$-actin primary antibody $(1 / 100$ 000; Novus Biologicals, Inc., Littleton, CO, USA) and with HRP-conjugated sheep anti-mouse IgG or donkey anti-rabbit (1/5000; Amersham). Immunoreactive bands were visualized with the ECL western blotting analysis system (GE HealthCare Biosciences, Inc., Montréal, Québec, Canada) and quantified by Alpha Imager software (Alpha Innotech Corporation). Results are expressed as densitometric units relative to $\beta$-actin.
Statistical analyses

Data are expressed as means \pm s.E.M. Results were tested for normality using a Shapiro-Wilk test. If normality could not be assumed, the data were normalized using a $\log _{10}$ transformation. The (normalized) data were tested for the effects and interactions of sex, IUGR, and $0 \cdot 9 \% \mathrm{NaCl}$ supplementation by the General Linear Model Univariate Analysis procedure (SPSS Statistics 16; IBM Company, Chicago, IL, USA). Since significant interactions were
A

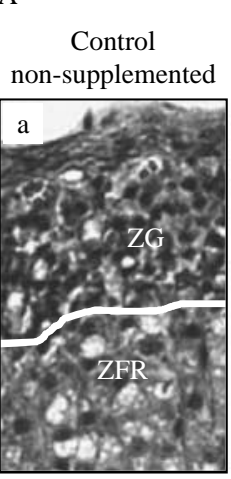

Males

\section{Control} $0.9 \% \mathrm{NaCl}$

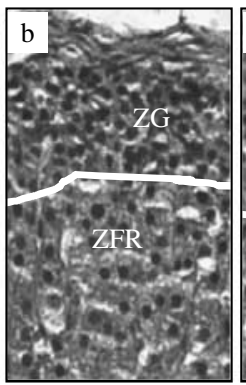

Females
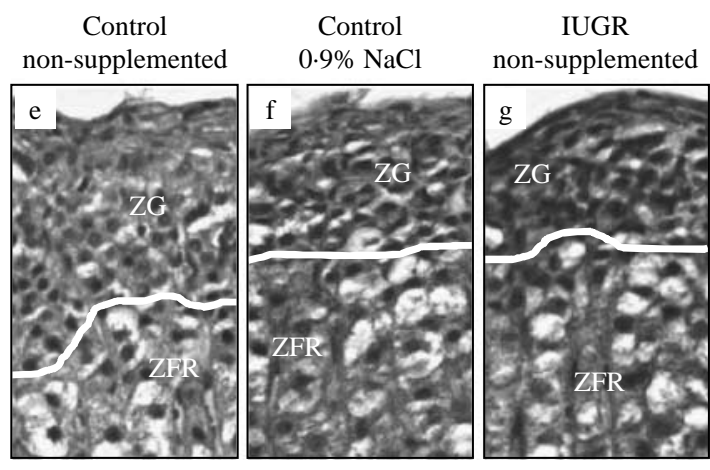

IUGR non-supplemented
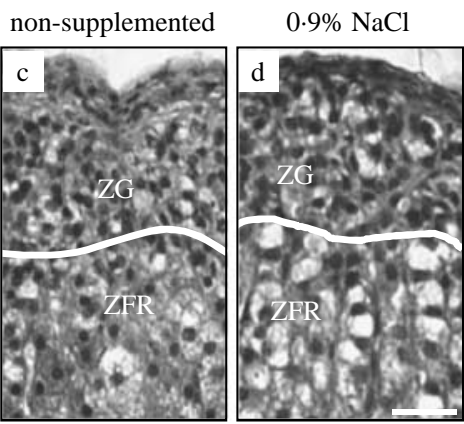

IUGR

Figure 1 Effects of IUGR and $0.9 \% \mathrm{NaCl}$ supplementation on adrenal zona glomerulosa width. Adrenal glands were immediately immersed in $4 \%$ paraformaldehyde and embedded in paraffin. Sections ( $5 \mu \mathrm{m}$ thick) were cut and stained with haematoxylin-eosin for general histological examination. (A) Representative illustration of adrenal gland cortex. Scale bar, $30 \mu \mathrm{m}$. ZG, zona glomerulosa and ZFR, zona fasciculata-reticularis. (B) Results are expressed as means \pm s.E.M. ( $n=5 /$ group). Salt-supplemented groups significantly different from their non-supplemented counterparts are indicated by $* P<0 \cdot 05$. 
found for sex in several parameters, all the studied parameters were analyzed separately for sex. Two-factor ANOVA was thus performed on the effects of IUGR and $0.9 \% \mathrm{NaCl}$ supplementation, followed by the Newman-Keuls multiple range test. Values were considered to be significantly different if $P<0 \cdot 05$. When significant interactions between IUGR and $0 \cdot 9 \% \mathrm{NaCl}$ supplementation were found, an unpaired Student's t-test was conducted to compare salt-supplemented groups to their non-supplemented counterpart as well as to compare both non-supplemented groups (IUGR versus control). Owing to multiple comparisons, the minimum level of statistical significance was then assumed to be $P<0 \cdot 05$.

\section{Results}

Effects of IUGR and $0.9 \% \mathrm{NaCl}$ supplementation on body weight and adrenal glands

Body weight at 12 weeks of age, as well as weight and relative weight of adrenal glands were unchanged between groups of males and females (Table 2).

Histological examination of the adrenal glands indicated that, in males, neither IUGR nor $0.9 \% \mathrm{NaCl}$ supplementation altered the width of the ZG (Fig. 1, a-d). In females, two-factor ANOVA analysis revealed that $\mathrm{NaCl}$ supplementation induced an important reduction in ZG width in IUGR animals (Fig. 1, h versus g, $P<0 \cdot 05$, Student's $t$-test, Fig. $1 \mathrm{~B}$, right panel).

\section{Effects of IUGR and $0.9 \% \mathrm{NaCl}$ supplementation on electrolytes and circulating hormonal levels}

Plasma sodium and potassium levels in males or in females were not affected by IUGR (data not shown). Similarly, $\mathrm{NaCl}$ supplementation did not modify plasma sodium concentrations in either male or female rats. However, plasma potassium levels in females but not in males were decreased by $\mathrm{NaCl}$ intake $(P<0 \cdot 05$, two-factor ANOVA).

In males, PRA was unaltered by IUGR (Fig. 2A, left panel) but was decreased in $\mathrm{NaCl}$ supplementation-treated rats, both in control and IUGR groups $(P<0 \cdot 05$, Newman-Keuls test). In females (Fig. 2A, right panel), PRA was similarly reduced in $\mathrm{NaCl}$-supplemented controls and in non-supplemented IUGR $(P<0 \cdot 05$, Newman-Keuls test). The presence of both conditions further reduced PRA.

Serum aldosterone levels were reduced by IUGR but only significantly in males (Fig. 2B). $\mathrm{NaCl}$ supplementation induced the expected decrease in aldosterone both in control and in IUGR rats, including both males and females. In contrast, serum corticosterone was not affected by IUGR or by $\mathrm{NaCl}$ supplementation in either males or females (Fig. 2C).

\section{Effects of IUGR and $0.9 \% \mathrm{NaCl}$ supplementation on $A T_{1} R$ and $A T_{2} R$ expression in adrenal $Z G$}

In males (Fig. 3A, left panel), IUGR increased $\mathrm{AT}_{1} \mathrm{R}$ mRNA levels compared with control groups $(P<0 \cdot 05$,
Newman-Keuls test). However, $\mathrm{NaCl}$ supplementation decreased the $\mathrm{AT}_{1} \mathrm{R}$ mRNA levels in both control and IUGR male groups $(P<0 \cdot 05$, Newman-Keuls test). At the protein level, $\mathrm{AT}_{1} \mathrm{R}$ protein expression was increased in nonsupplemented IUGR males compared with their controls $(P<0 \cdot 05$, Student's $t$-test; Fig. 3B, left panel). Moreover, $\mathrm{NaCl}$ intake had an opposite effect in control and IUGR groups. Indeed, a small increase was observed in control animals $(P=0 \cdot 06$, Student's $t$-test), conversely to a decrease in IUGR animals $(P<0 \cdot 05$, Student's $t$-test $)$. In females, both IUGR and $\mathrm{NaCl}$ supplementation had no effect on either $A T_{1} \mathrm{R}$ mRNA or protein expression (Fig. $3 \mathrm{~A}$ and $\mathrm{B}$, right panel).

In males, $\mathrm{AT}_{2} \mathrm{R}$ mRNA expression was increased by IUGR and decreased by $\mathrm{NaCl}$ supplementation (Fig. 4A, left panel; $P<0 \cdot 05$, Newman-Keuls test), similarly to that observed for $\mathrm{AT}_{1} \mathrm{R}$ mRNA expression. Surprisingly, protein
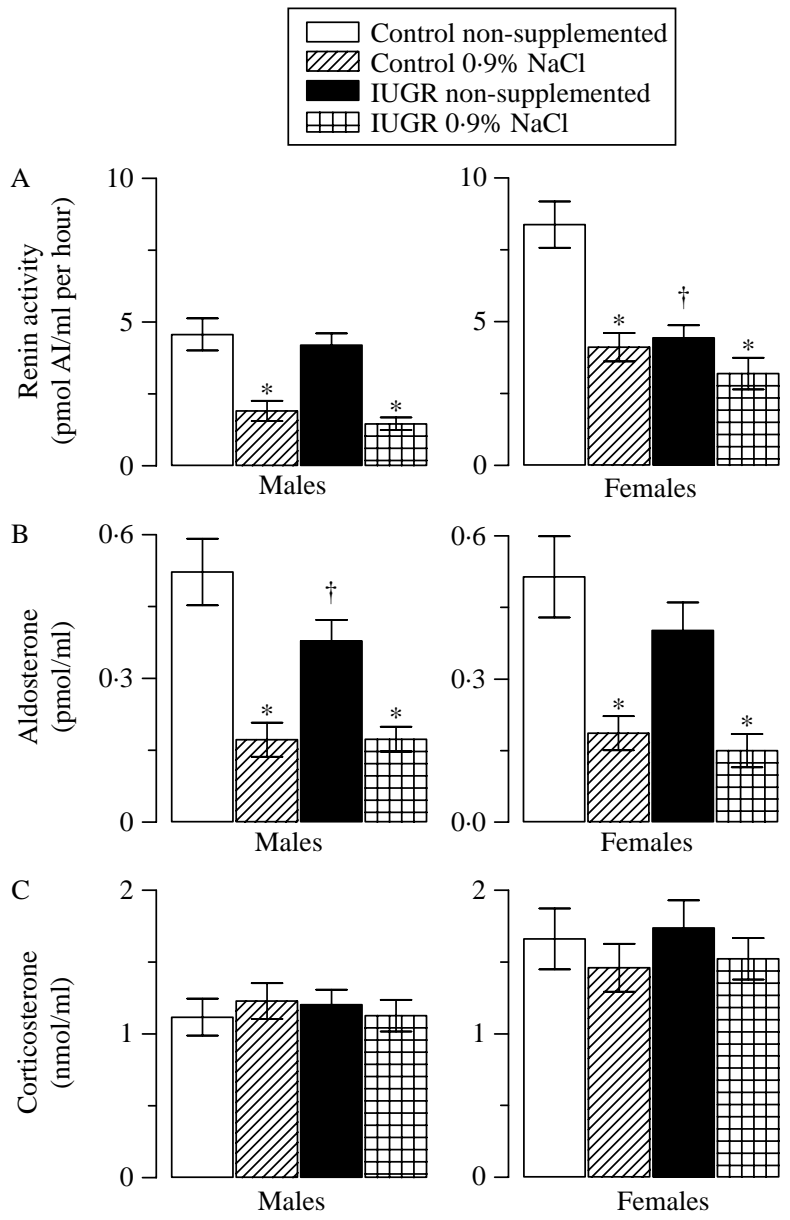

Females

Figure 2 Effects of IUGR and $0.9 \% \mathrm{NaCl}$ supplementation on (A) plasma renin activity, (B) serum aldosterone, and (C) serum corticosterone in 12-week-old control and IUGR animals. Results are expressed as means \pm S.E.M. ( $n=17-26$ rats per group). Salt-supplemented groups significantly different from their non-supplemented counterparts are indicated by $* P<0 \cdot 05$, while non-supplemented groups significantly different from each other are indicated by ${ }^{+} P<0 \cdot 05$. 
A mRNA expression

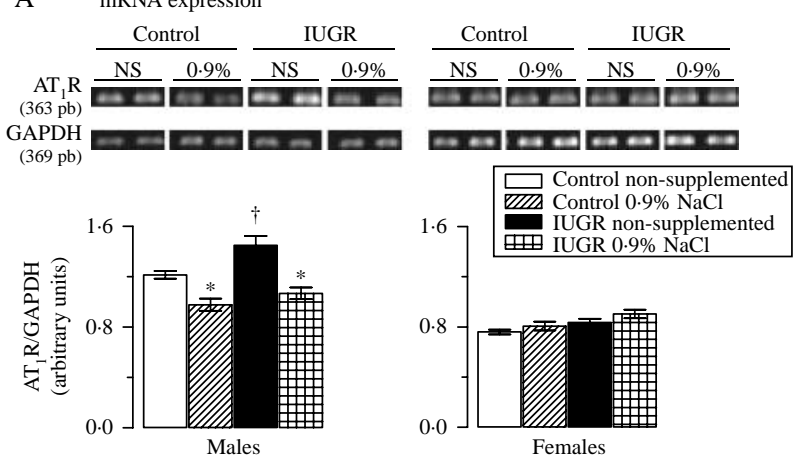

B Protein expression
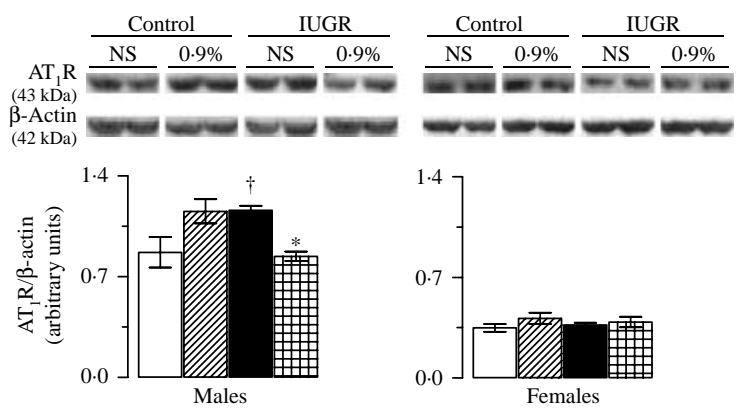

Figure 3 Effects of $0.9 \% \mathrm{NaCl}$ supplementation on the expression of $\mathrm{AT}_{1} \mathrm{R}$ mRNA (A) and protein (B) in adrenal zona glomerulosa from 12-week-old control and IUGR rats. Representative gels for PCR amplification products and immunoblots are shown. For purposes of conciseness, two samples/group are illustrated. Data from densitometric analysis are expressed in arbitrary units. Results are expressed as means \pm s.E.M. ( $n=6 /$ group). Salt-supplemented groups significantly different from their non-supplemented counterparts are indicated by ${ }^{*} P<0 \cdot 05$, while non-supplemented groups significantly different from each other are indicated by ${ }^{+} P<0 \cdot 05$.

expression was not influenced by IUGR, but was enhanced by $\mathrm{NaCl}$ intake $(P<0 \cdot 05$, two-factor ANOVA; Fig. 4B, left panel). In females, IUGR increased $\mathrm{AT}_{2} \mathrm{R}$ mRNA expression (Fig. 4A, right panel; $P<0 \cdot 05$, Newman-Keuls test) and decreased protein expression (Fig. 4B, right panel; $P<0 \cdot 05$, two-factor ANOVA). $\mathrm{NaCl}$ supplementation did not show any effect on expression of $\mathrm{AT}_{2} \mathrm{R}$ mRNA nor protein.

\section{Effects of IUGR and $\mathrm{NaCl}$ supplementation on steroidogenesis in adrenal $Z G$}

In males, as observed for $\mathrm{AT}_{1} \mathrm{R}$ and $\mathrm{AT}_{2} \mathrm{R}, \mathrm{P} 450 \mathrm{aldo}$ mRNA expression was increased by IUGR and decreased by $\mathrm{NaCl}$ supplementation (Fig. 5A, left panel; $P<0 \cdot 05$, two-factor ANOVA). A similar pattern was also observed for protein expression (Fig. 5B, left panel; $P<0 \cdot 05$, twofactor ANOVA). In females, IUGR had no effect on P450aldo mRNA expression, which was decreased by $\mathrm{NaCl}$ supplementation. (Fig. 5A, right panel; $P<0 \cdot 05$, Newman-Keuls test). Protein expression was decreased by IUGR and $\mathrm{NaCl}$ supplementation (Fig. 5B; $P<0 \cdot 05$, two-factor ANOVA).
In males, P45011 $\beta$ mRNA expression was not affected by IUGR or by $0.9 \% \mathrm{NaCl}$ supplementation (Fig. 6A, left panel), although protein level was increased by $\mathrm{NaCl}$ supplementation $(P<0.05$, two-factor ANOVA, Fig. 6B left panel). In females, P45011 $\beta$ mRNA expression was increased only in IUGR $\mathrm{NaCl}$-supplemented animals (Fig. 6A, right panel; $P<0 \cdot 05$, two-factor ANOVA). Protein level was not affected by IUGR or by $\mathrm{NaCl}$ supplementation (Fig. 6B, right panel).

\section{Discussion}

The present study was undertaken to assess the consequences of IUGR on the expression of Ang II receptors and on adrenal steroidogenesis enzymes in the adult rat submitted to excess sodium ingestion, a condition often observed in the human adult population. We show herein that, in adult males, mRNA expression of Ang II receptors, both $\mathrm{AT}_{1} \mathrm{R}$ and $\mathrm{AT}_{2} \mathrm{R}$, as well as of P450aldo was increased by IUGR, while sodium supplementation consistently decreased this expression. Female rats hardly manifested any changes in the

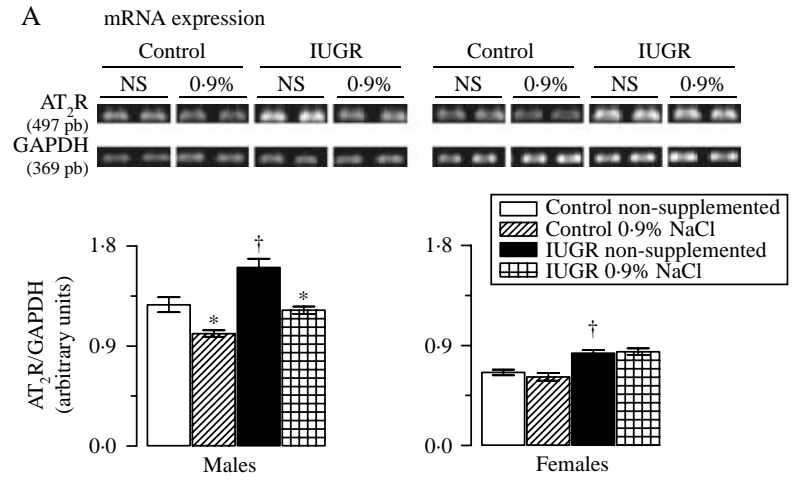

B Protein expression
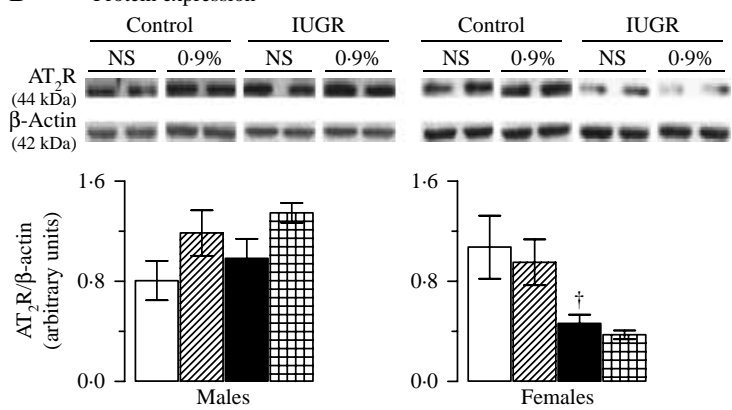

Figure 4 Effects of $0.9 \% \mathrm{NaCl}$ supplementation on the expression of $\mathrm{AT}_{2} \mathrm{R}$ mRNA (A) and protein (B) in adrenal zona glomerulosa from 12-week-old control and IUGR rats. Representative gels for PCR amplification products and immunoblots are shown. For purposes of conciseness, two samples/group are illustrated. Data from densitometric analysis are expressed in arbitrary units. Results are expressed as means \pm s.E.M. ( $n=6 /$ group). Salt-supplemented groups significantly different from their non-supplemented counterparts are indicated by $* P<0 \cdot 05$, while non-supplemented groups significantly different from each other are indicated by ${ }^{+} P<0 \cdot 05$. 
A
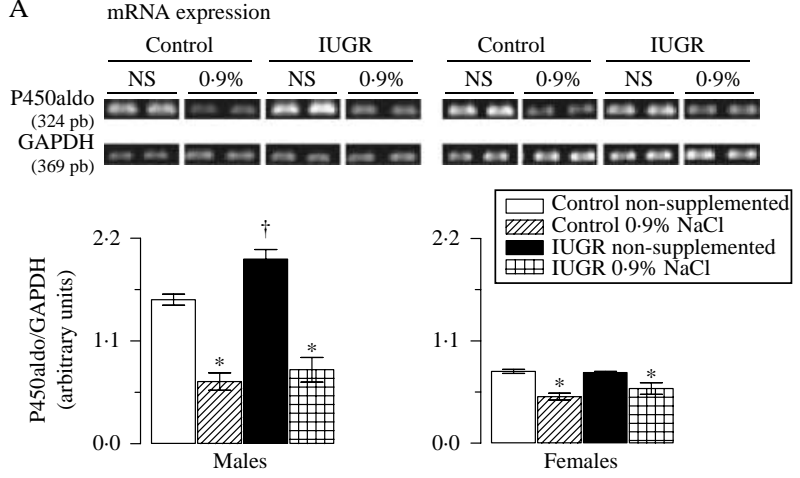

B
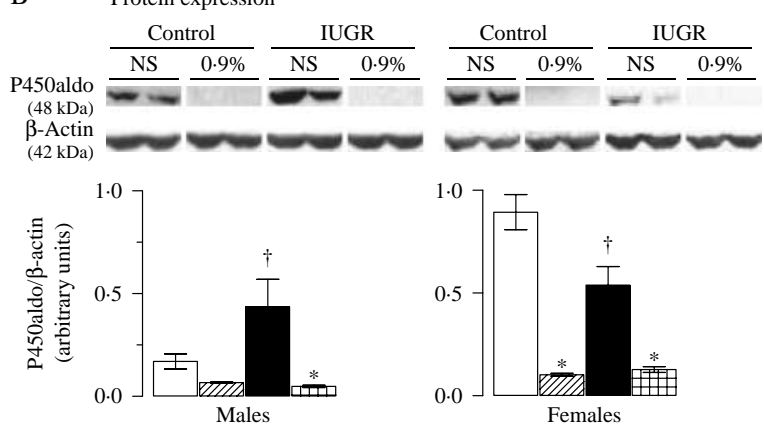

Figure 5 Effects of $0 \cdot 9 \% \mathrm{NaCl}$ supplementation on the expression of P450aldo mRNA (A) and protein (B) in adrenal zona glomerulosa from 12-week-old control and IUGR rats. Representative gels for PCR amplification products and immunoblots are shown. For purposes of conciseness, two samples/group are illustrated. Data from densitometric analysis are expressed in arbitrary units. Results are expressed as means \pm s.E.M. ( $n=6 /$ group). Salt-supplemented groups significantly different from their non-supplemented counterparts are indicated by $* P<0 \cdot 05$, while non-supplemented groups significantly different from each other are indicated by ${ }^{+} P<0 \cdot 05$

above mRNA expressions in response to IUGR and/or $\mathrm{NaCl}$ supplementation, except for P450aldo, which was decreased by the latter condition. Protein expression of $\mathrm{AT}_{1} \mathrm{R}, \mathrm{AT}_{2} \mathrm{R}$, and $\mathrm{P} 450$ aldo was less consistently altered by the experimental conditions, except for P450aldo which was decreased by $\mathrm{NaCl}$ supplementation. These results demonstrate that IUGR has different sex-related impacts on the RAAS and adrenal mineralocorticoid synthesis following $\mathrm{NaCl}$ supplementation.

\section{Adrenal changes induced by IUGR}

It is quite striking that an adverse foetal environment impacts differentially the adult male and female adrenal glands. With regard to gland morphology, the size of the adrenal ZG was not altered by IUGR. From a regulatory point of view, increased $\mathrm{AT}_{1} \mathrm{R}$ expression (mRNA and protein) was associated with increased P450aldo (mRNA and protein) in males, whereas no such relationship was observed in females. In fact, P450aldo protein levels were decreased along with an increase in $\mathrm{AT}_{2} \mathrm{R}$ mRNA expression and a decrease in $\mathrm{AT}_{2} \mathrm{R}$ protein levels. This discordance between mRNA and protein expression could be linked to the various regulatory mechanisms involved in translational and post-translational regulation ( $\mathrm{Li}$ et al. 1999, Zhang et al. 2004). Contrary to Lopes et al. (2008), who also used a low-sodium diet to induce IUGR in rats, PRA was not altered in IUGR males but was reduced in IUGR females. This discrepancy is undoubtedly linked to the timing of the diet ( 4 weeks before mating and throughout gestation versus end of the 3 weeks of gestation in this study) and by the severity of sodium restriction ( 0.15 vs $0.03 \%$ herein). Nonetheless, the above reports strongly suggest that adverse foetal environment has different impacts on RAAS regulation. Indeed, Bogdarina et al. have studied the epigenetic RAS in foetal programming of hypertension. They showed a link between foetal insults (maternal lowprotein diet) and epigenetic modification of genes at 1 week of age (Bogdarina et al. 2007). The authors also demonstrated that, later in life, changes in expression of certain genes, including $\mathrm{AT}_{1 \mathrm{~b}}$, were likely to be secondary to development
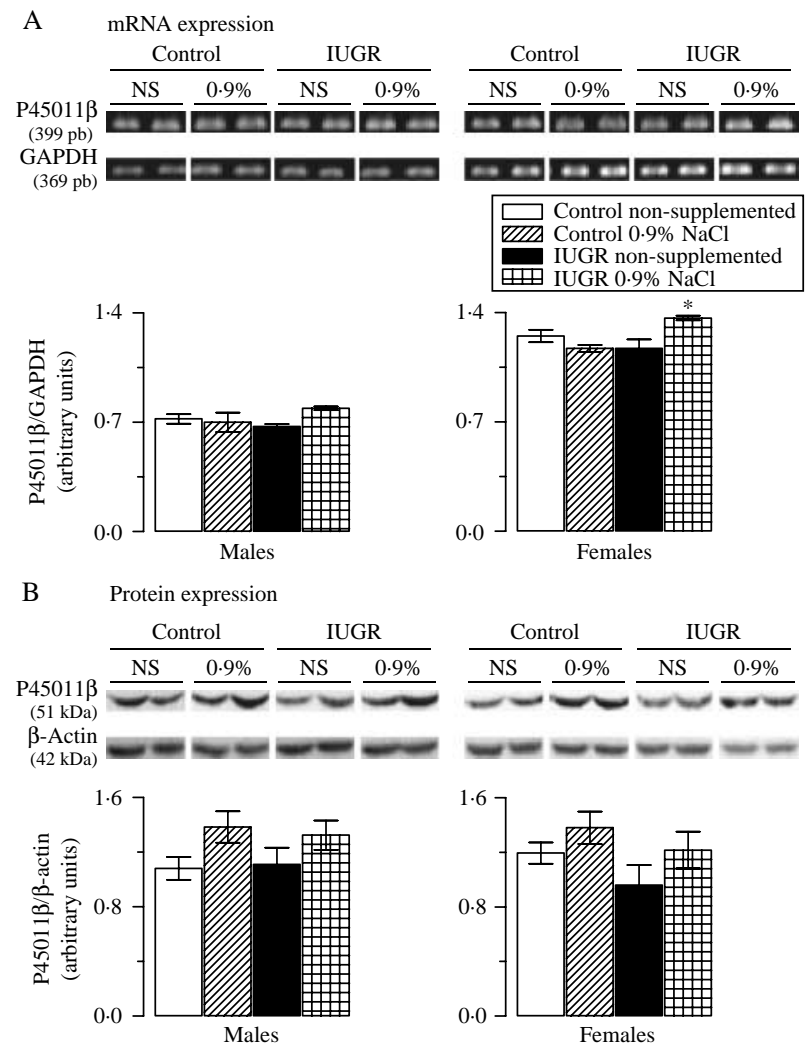

Figure 6 Effects of $0.9 \% \mathrm{NaCl}$ supplementation on the expression of P45011 $\beta$ mRNA (A) and protein (B) in adrenal zona glomerulosa from 12-week-old control and IUGR rats. Representative gels for PCR amplification products and immunoblots are shown. For purposes of conciseness, two samples/group are illustrated. Data from densitometric analysis are expressed in arbitrary units. Results are expressed as means \pm s.E.M. ( $n=6 /$ group). Salt-supplemented groups significantly different from their non-supplemented counterparts are indicated by $* P<0 \cdot 05$. 
of hypertension (Bogdarina et al. 2007), suggesting that gene expression is differently regulated with age. A role for glucocorticoids in $\mathrm{AT}_{1 \mathrm{~b}}$ gene expression was also shown (Bogdarina et al. 2010).

In the present study, circulating aldosterone levels were reduced in IUGR versus controls, despite altered adrenal P450aldo expression (increase in males and decrease in females). The discrepancy between circulating aldosterone levels and P450aldo mRNA and protein expression in males is quite surprising. This suggests that, in IUGR males, other factors are implicated in the modulation of P450aldo activity. It could be that the electron transfer rate by the NADPHlinked redox system (adrenodoxin and adrenodoxin reductase; Lisurek \& Bernhardt 2004) or the membrane composition of the mitochondria may affect mitochondrial cholesterol trafficking (Seybert 1990, Jefcoate 2002). The amount of precursors may also be responsible for these differences. It is speculated that this regulation is exerted at the level of cytochrome P450 side-chain cleavage, the first enzyme in steroidogenesis (Brochu et al. 1991), by a post-translational phosphorylation of the enzyme (Bureik et al. 2002). Since past research on the regulation of mitochondrial steroid hydroxylase systems has focused on the transcriptional level and not on post-translational modifications, further studies are needed to identify the specific mechanism(s) involved. The present data confirm, however, that an adverse foetal environment can induce long-term changes in adrenal glands that are influenced by the sex of the affected offspring.

\section{Adrenal changes induced by $\mathrm{NaCl}$ supplementation}

$\mathrm{NaCl}$ supplementation markedly reduced PRA, serum aldosterone, $\mathrm{AT}_{1} \mathrm{R}$ expression (protein and $\mathrm{mRNA}$ in males), $\mathrm{AT}_{2} \mathrm{R}$ mRNA (also in males) and protein expression (females) as well as $\mathrm{P} 450$ aldo expression (mRNA and protein in both sexes). Such reduction in RAAS activity following high-salt intake is well documented (Sagnella et al. 1990, Cholewa \& Mattson 2001). Reduction in the size of adrenal $\mathrm{ZG}$ in females under $\mathrm{NaCl}$ supplementation is in agreement with the observations reported by Hartroft \& Hartroft (1955). However, no such observation was found in males, again suggesting sex-related changes of the adrenal ZG in response to $\mathrm{NaCl}$ supplementation in IUGR animals. The discrepancy between this previous study (Hartroft \& Hartroft 1955) and the present findings in males could be explained by the use of a different strain of rats (Wistar versus Sprague-Dawley). Indeed, response to treatment has been reported to be influenced by rat strains (Garland et al. 1989) and even by rat suppliers (Pollock \& Rekito 1998). Proliferation of glomerulosa cells has been shown to be controlled by Ang II and mediated by $\mathrm{AT}_{1} \mathrm{R}$-dependent and -independent processes (McEwan et al. 1999). The mechanisms implicated in the atrophy of this zone by salt supplementation are not well characterized, although apoptosis could be involved (McEwan et al. 1996a).
In control males, $\mathrm{NaCl}$ supplementation decreased mRNA levels but increased protein expression for both $\mathrm{AT}_{1 \mathrm{~b}} \mathrm{R}$ and $\mathrm{AT}_{2} \mathrm{R}$ compared with non-supplemented animals. Following $\mathrm{NaCl}$ supplementation, decreased Ang II levels would preclude any down-regulation in receptor protein expression, even leading to a certain relative increase in levels compared with non-supplemented control rats. This could also apply for $\mathrm{AT}_{2} \mathrm{R}$ expression levels in IUGR males. However, for $\mathrm{AT}_{1} \mathrm{R}$ expression, IUGR affected the response to $\mathrm{NaCl}$ supplementation (decreased mRNA and protein compared with non-supplemented IUGR), suggesting a different regulatory control in these animals. In control and IUGR females, $\mathrm{NaCl}$ supplementation was not found to be a major regulator of $\mathrm{AT}_{1} \mathrm{R}$ and $\mathrm{AT}_{2} \mathrm{R}$ expression, again indicating differential responses between males and females to salt supplementation. To date, the majority of experiments reported on the regulation of ATR have been performed using low-sodium intake or plasma Ang II infusions (McEwan et al. 1996b, 1999, Mulrow 1999). To our knowledge, the few studies available concerning salt supplementation on both mRNA and protein expression of $\mathrm{AT}_{1} \mathrm{R}$ and $\mathrm{AT}_{2} \mathrm{R}$ are somewhat inconsistent. While lower $\mathrm{AT}_{1} \mathrm{R}$ protein expression (Nora et al. 2000) and reduced number of $\mathrm{AT}_{1} \mathrm{R}$ binding sites (Douglas \& Catt 1976) following high-salt intake have been described, other studies meanwhile have shown unaltered $\mathrm{AT}_{1} \mathrm{R}$ mRNA expression (Jo et al. 1996, Schmid et al. 1997). Only one study has reported an absence of effect of salt supplementation on $\mathrm{AT}_{2} \mathrm{R}$ protein expression in the rat adrenal gland (Nora et al. 2000).

While $\mathrm{AT}_{2} \mathrm{R}$ expression is low in several adult tissues, there is a general consensus that $\mathrm{AT}_{2} \mathrm{R}$ promotes vasodilatation, growth inhibition, cell differentiation and apoptosis (de Gasparo et al. 2000, St-Louis et al. 2001, Gendron et al. 2003). However, in the adrenal $\mathrm{ZG}, \mathrm{AT}_{2} \mathrm{R}$ expression is maintained at a high level, even in the adult (Breault et al. 1996, Frei et al. 2001). Its role is not yet clearly defined, since it does not modify proliferation or protein synthesis in isolated cells (Otis et al. 2005). However, several recent data have suggested that $\mathrm{AT}_{2} \mathrm{R}$ may ensure a protective role not only in the cardiovascular and renal systems (Carey \& Padia 2008, Siragy 2009), but also in metabolic homeostasis, brain disorders and even in cancer (for reviews, see Henriksen (2007), Roberge et al. (2007), Horiuchi et al. (2010) and Steckelings et al. (2010)). The change in protein levels of $\mathrm{AT}_{1} \mathrm{R}$ and $\mathrm{AT}_{2} \mathrm{R}$ in IUGR males in the present study led to a decrease in $A T_{1} R$ to $A T_{2} R$ ratio, which may have contributed to the observed reduction in aldosterone synthesis. In these conditions, Ang II binding to the $\mathrm{AT}_{2} \mathrm{R}$ may counteract the stimulation of aldosterone synthesis induced through the $\mathrm{AT}_{1} \mathrm{R}$. Conversely, in control males and in both groups of females, Ang II receptor expression does not explain the observed decrease in P450aldo and aldosterone levels. In fact, a long list of compensatory factors may be involved, since it is already known that aldosterone secretion is under multifactorial regulation, even if Ang II is considered as its most important modulator 
(Ehrhart-Bornstein et al. 1998). As also shown by Ye et al. (2003), P45011 $\beta$ mRNA did not respond herein to salt supplementation in control males and females. However, an increase was noted in IUGR females, suggesting again that the sex of these IUGR animals influences the response to salt intake.

In summary, the present study shows that adult male and female rats submitted to IUGR exhibit differential responses regarding the expression of both $\mathrm{AT}_{1 \mathrm{~b}}$ and $\mathrm{AT}_{2}$ receptors of Ang II, as well as aldosterone synthesis, in controls and under $\mathrm{NaCl}$ supplementation. Moreover, salt supplementation affected mRNA as well as protein expression for both receptor subtypes in males, as opposed to females where supplementation was not found to be a major regulator, again indicating sex-related differences. However, our results suggest that impaired adrenal steroidogenesis is compensated by extra- and intra-adrenal factors which enable to cope with $\mathrm{NaCl}$ supplementation.

\section{Declaration of interest}

The authors declare that there is no conflict of interest that could be perceived as prejudicing the impartiality of the research reported.

\section{Funding}

This work was supported by grants from the Natural Sciences and Engineering Research Council of Canada (NSERC). Personal support was provided by NSERC to K B (studentship).

\section{References}

Bassett MH, White PC \& Rainey WE 2004 The regulation of aldosterone synthase expression. Molecular and Cellular Endocrinology 217 67-74. (doi:10.1016/j.mce.2003.10.011)

Battista MC, Oligny LL, St-Louis J \& Brochu M 2002 Intrauterine growth restriction in rats is associated with hypertension and renal dysfunction in adulthood. American Journal of Physiology. Endocrinology and Metabolism 283 E124-E131. (doi:10.1152/ajpendo.00004.2001)

Battista MC, Calvo E, Chorvatova A, Comte B, Corbeil J \& Brochu M 2005 Intra-uterine growth restriction and the programming of left ventricular remodelling in female rats. Journal of Physiology 565 197-205. (doi:10.1113/ jphysiol.2004.078139)

Bedard S, Sicotte B, St-Louis J \& Brochu M 2005 Modulation of body fluids and angiotensin II receptors in a rat model of intra-uterine growth restriction. Journal of Physiology 562 937-950. (doi:10.1113/jphysiol.2004. 064683)

Bibeau K, Battista MC, Houde V \& Brochu M 2010 Fetal adrenal gland alterations in a rat model of adverse intrauterine environment. American Journal of Physiology. Regulatory, Integrative and Comparative Physiology 298 R899-R911. (doi:10.1152/ajpregu.00238.2009)

Bogdarina I, Welham S, King PJ, Burns SP \& Clark AJ 2007 Epigenetic modification of the renin-angiotensin system in the fetal programming of hypertension. Circulation Research 100 520-526. (doi:10.1161/01.RES. 0000258855.60637.58)

Bogdarina I, Haase A, Langley-Evans S \& Clark AJ 2010 Glucocorticoid effects on the programming of $\mathrm{AT}_{1 \mathrm{~b}}$ angiotensin receptor gene methylation and expression in the rat. PLoS ONE 5 e9237. (doi:10.1371/journal.pone. 0009237)
Breault L, Lehoux JG \& Gallo-Payet N 1996 The angiotensin AT2 receptor is present in the human fetal adrenal gland throughout the second trimester of gestation. Journal of Clinical Endocrinology and Metabolism 81 3914-3922. (doi:10.1210/jc.81.11.3914)

Brochu M, Ong H \& De Léan A 1991 Sites of action of angiotensin II, atrial natriuretic factor and guanabenz, on aldosterone biosynthesis. Journal of Steroid Biochemistry and Molecular Biology 38 575-582. (doi:10.1016/09600760(91)90315-V)

Bureik M, Lisurek M \& Bernhardt R 2002 The human steroid hydroxylases CYP1B1 and CYP11B2. Biological Chemistry 383 1537-1551. (doi:10. 1515/BC.2002.174)

Capponi AM 2004 The control by angiotensin II of cholesterol supply for aldosterone biosynthesis. Molecular and Cellular Endocrinology 217 113-118. (doi:10.1016/j.mce.2003.10.055)

Carey RM \& Padia SH 2008 Angiotensin AT2 receptors: control of renal sodium excretion and blood pressure. Trends in Endocrinology and Metabolism 19 84-87. (doi:10.1016/j.tem.2008.01.003)

Cholewa BC \& Mattson DL 2001 Role of the renin-angiotensin system during alterations of sodium intake in conscious mice. American Journal of Physiology. Regulatory, Integrative and Comparative Physiology 281 R987-R993.

Clark KE, Irion GL \& Mack CE 1990 Differential responses of uterine and umbilical vasculatures to angiotensin II and norepinephrine. American Journal of Physiology 259 H197-H203.

Douglas J \& Catt KJ 1976 Regulation of angiotensin II receptors in the rat adrenal cortex by dietary electrolytes. Journal of Clinical Investigation $\mathbf{5 8}$ 834-843. (doi:10.1172/JCI108536)

Ehrhart-Bornstein M, Hinson JP, Bornstein SR, Scherbaum WA \& Vinson GP 1998 Intraadrenal interactions in the regulation of adrenocortical steroidogenesis. Endocrine Reviews 19 101-143. (doi:10.1210/er.19.2.101)

Frei N, Weissenberger J, Beck-Sickinger AG, Hofliger M, Weis J \& Imboden H 2001 Immunocytochemical localization of angiotensin II receptor subtypes and angiotensin II with monoclonal antibodies in the rat adrenal gland. Regulatory Peptides 101 149-155. (doi:10.1016/S0167-0115 (01)00278-6)

Garland EM, Sakata T, Fisher MJ, Masui T \& Cohen SM 1989 Influences of diet and strain on the proliferative effect on the rat urinary bladder induced by sodium saccharin. Cancer Research 49 3789-3794.

Gasc JM, Shanmugam S, Sibony M \& Corvol P 1994 Tissue-specific expression of type 1 angiotensin II receptor subtypes. An in situ hybridization study. Hypertension 24 531-537.

de Gasparo M, Catt KJ, Inagami T, Wright JW \& Unger T 2000 International Union of Pharmacology. XXIII. The angiotensin II receptors. Pharmacological Reviews $\mathbf{5 2}$ 415-472.

Gendron L, Payet MD \& Gallo-Payet N 2003 The angiotensin type 2 receptor of angiotensin II and neuronal differentiation: from observations to mechanisms. Journal of Molecular Endocrinology 31 359-372. (doi:10.1677/ jme.0.0310359)

Gutkowska J, Boucher R \& Genest J 1977 Radioimmunologic determination of plasma renin activity. L'Unión Médicale du Canada 106 446-450.

Hartroft PM \& Hartroft WS 1955 Studies on renal juxtaglomerular cells. II. Correlation of the degree of granulation of juxtaglomerular cells with width of the zone glomerulosa of the adrenal cortex. Journal of Experimental Medicine 102 205-212. (doi:10.1084/jem.102.2.205)

Henriksen EJ 2007 Improvement of insulin sensitivity by antagonism of the renin-angiotensin system. American Journal of Physiology. Regulatory, Integrative and Comparative Physiology 293 R974-R980. (doi:10.1152/ ajpregu.00147.2007)

Horiuchi M, Mogi M \& Iwai M 2010 The angiotensin II type 2 receptor in the brain. Journal of Renin-Angiotensin-Aldosterone System 11 1-6. (doi:10.1177/1470320309347793)

Hunyady L \& Catt KJ 2006 Pleiotropic AT1 receptor signaling pathways mediating physiological and pathogenic actions of angiotensin II. Molecular Endocrinology 20 953-970. (doi:10.1210/me.2004-0536)

Jefcoate C 2002 High-flux mitochondrial cholesterol trafficking, a specialized function of the adrenal cortex. Journal of Clinical Investigation 110 881-890. (doi:10.1172/JCI16771) 
Jo H, Yang EK, Lee WJ, Park KY, Kim HJ \& Park JS 1996 Gene expression of central and peripheral renin-angiotensin system components upon dietary sodium intake in rats. Regulatory Peptides 67 115-121. (doi:10.1016/S01670115(96)00119-X)

Li JY, Avallet O, Berthelon MC, Langlois D \& Saez JM 1999 Transcriptional and translational regulation of angiotensin II type 2 receptor by angiotensin II and growth factors. Endocrinology 140 4988-4994. (doi:10.1210/en.140. 11.4988)

Lisurek M \& Bernhardt R 2004 Modulation of aldosterone and cortisol synthesis on the molecular level. Molecular and Cellular Endocrinology 215 149-159. (doi:10.1016/j.mce.2003.11.008)

Lopes KL, Furukawa LN, de Oliveira IB, Dolnikoff MS \& Heimann JC 2008 Perinatal salt restriction: a new pathway to programming adiposity indices in adult female Wistar rats. Life Sciences 82 728-732. (doi:10.1016/j.lfs. 2008.01.003)

Macova M, Armando I, Zhou J, Baiardi G, Tyurmin D, Larrayoz-Roldan IM \& Saavedra JM 2008 Estrogen reduces aldosterone, upregulates adrenal angiotensin II AT2 receptors and normalizes adrenomedullary Fra-2 in ovariectomized rats. Neuroendocrinology 88 276-286. (doi:10.1159/ 000150977)

McEwan PE, Lindop GB \& Kenyon CJ 1996a Control of cell proliferation in the rat adrenal gland in vivo by the renin-angiotensin system. American Journal of Physiology 271 E192-E198.

McEwan PE, Vinson GP \& Kenyon CJ $1996 b$ AT1 receptors and cell proliferation in rat adrenals: effects of angiotensin infusion, low sodium diet and losartan. Endocrine Research 22 369-371.

McEwan PE, Vinson GP \& Kenyon CJ 1999 Control of adrenal cell proliferation by AT1 receptors in response to angiotensin II and lowsodium diet. American Journal of Physiology 276 E303-E309.

McMillen IC \& Robinson JS 2005 Developmental origins of the metabolic syndrome: prediction, plasticity, and programming. Physiological Reviews $\mathbf{8 5}$ 571-633. (doi:10.1152/physrev.00053.2003)

Meneton P, Jeunemaitre X, De Wardener HE \& MacGregor GA 2005 Links between dietary salt intake, renal salt handling, blood pressure, and cardiovascular diseases. Physiological Reviews 85 679-715. (doi:10.1152/ physrev.00056.2003)

Mulrow PJ 1999 Angiotensin II and aldosterone regulation. Regulatory Peptides 80 27-32. (doi:10.1016/S0167-0115(99)00004-X)

Nora EH, Tonellato PJ \& Greene AS 2000 Quantification of the contribution of type 1 and type 2 angiotensin II receptors to the net tissue specific effect of angiotensin II. Annals of Biomedical Engineering 28 653-664. (doi:10. $1114 / 1.1305911)$

Otis M \& Gallo-Payet N 2007 Role of MAPKs in angiotensin II-induced steroidogenesis in rat glomerulosa cells. Molecular and Cellular Endocrinology 265-266 126-130. (doi:10.1016/j.mce.2006.12.008)

Otis M, Campbell S, Payet MD \& Gallo-Payet N 2005 Angiotensin II stimulates protein synthesis and inhibits proliferation in primary cultures of rat adrenal glomerulosa cells. Endocrinology 146 633-642. (doi:10.1210/en.2004-0935)

Otis M, Campbell S, Payet MD \& Gallo-Payet N 2007 The growth-promoting effects of angiotensin II in adrenal glomerulosa cells: an interactive tale. Molecular and Cellular Endocrinology 273 1-5. (doi:10.1016/j.mce.2007.05.006)
Pollock DM \& Rekito A 1998 Hypertensive response to chronic NO synthase inhibition is different in Sprague-Dawley rats from two suppliers. American Journal of Physiology 275 R1719-R1723.

Roberge C, Carpentier AC, Langlois MF, Baillargeon JP, Ardilouze JL, Maheux P \& Gallo-Payet N 2007 Adrenocortical dysregulation as a major player in insulin resistance and onset of obesity. American Journal of Physiology. Endocrinology and Metabolism 293 E1465-E1478. (doi:10.1152/ ajpendo.00516.2007)

Roy-Clavel E, Picard S, St-Louis J \& Brochu M 1999 Induction of intrauterine growth restriction with a low-sodium diet fed to pregnant rats. American Journal of Obstetrics and Gynecology 180 608-613. (doi:10.1016/ S0002-9378(99)70262-0)

Sagnella GA, Markandu ND, Buckley MG, Miller MA, Singer DR \& MacGregor GA 1990 Plasma atrial natriuretic peptide, aldosterone, and plasma renin activity responses to gradual changes in dietary sodium intake. American Journal of Hypertension 3 863-865.

Schiffrin EL \& Touyz RM 2004 From bedside to bench to bedside: role of renin-angiotensin-aldosterone system in remodeling of resistance arteries in hypertension. American Journal of Physiology. Heart and Circulatory Physiology 287 H435-H446. (doi:10.1152/ajpheart.00262.2004)

Schmid C, Castrop H, Reitbauer J, Della BR \& Kurtz A 1997 Dietary salt intake modulates angiotensin II type 1 receptor gene expression. Hypertension 29 923-929.

Seybert DW 1990 Lipid regulation of bovine cytochrome P450(11) beta activity. Archives of Biochemistry and Biophysics 279 188-194. (doi:10.1016/ 0003-9861(90)90480-M)

Siragy HM 2009 The potential role of the angiotensin subtype 2 receptor in cardiovascular protection. Current Hypertension Reports 11 260-262. (doi:10. 1007/s11906-009-0044-3)

Steckelings UM, Rompe F, Kaschina E, Namsolleck P, Grzesiak A, Funke-Kaiser H, Bader M \& Unger T 2010 The past, present and future of angiotensin II type 2 receptor stimulation. Journal of Renin-AngiotensinAldosterone System 11 67-73. (doi:10.1177/1470320309347791)

St-Louis J, Sicotte B, Bedard S \& Brochu M 2001 Blockade of angiotensin receptor subtypes in arcuate uterine artery of pregnant and postpartum rats. Hypertension 38 1017-1023. (doi:10.1161/hy1101.095008)

Ye P, Kenyon CJ, MacKenzie SM, Seckl JR, Fraser R, Connell JM \& Davies E 2003 Regulation of aldosterone synthase gene expression in the rat adrenal gland and central nervous system by sodium and angiotensin II. Endocrinology 144 3321-3328. (doi:10.1210/en.2003-0109)

Zhang Y, Ji H, Fabucci ME, Falconetti C, Zheng W \& Sandberg K 2004 Translational control of the rat angiotensin type 1a receptor by alternative splicing. Gene 341 93-100. (doi:10.1016/j.gene.2004.07.017)

\section{Received in final form 26 January 2011 \\ Accepted 8 February 2011 \\ Made available online as an Accepted Preprint 8 February 2011}

